\title{
Szív-elektrofiziológiai vizsgálatok és katéterablációk számának alakulása Magyarországon 2014 és 2016 között
}

\author{
Tahin Tamás', Riba Ádám¹, Clemens Marcell², Földesi Csaba³, Duray Gábor", \\ Gellér László ${ }^{5}$, Merkely Béla ${ }^{5}$, Sághy László ${ }^{6}$
}

\author{
1Zala Megyei Szt. Rafael Kórház, Zalaegerszeg \\ ${ }^{2}$ Debreceni Egyetem OEC, Debrecen \\ ${ }^{3}$ Gottsegen György Országos Kardiológiai Intézet, Budapest \\ ${ }^{4} \mathrm{MH}$ Egészségügyi Központ, Budapest \\ ${ }^{5}$ Semmelweis Egyetem, Városmajori Szív- és Érgyógyászati Klinika, Budapest \\ ${ }^{6}$ Szegedi Tudományegyetem, II. sz. Begyógyászati Klinika és Kardiológiai Központ, Szeged
}

Levelezési cím: Dr. Tahin Tamás, 8900 Zalaegerszeg, Zrínyi M. u. 1. E-mail: ttahin@gmail.com

A 2014-16-os években a korábban észlelt trend folytatódott a magyarországi katéterablációs beavatkozások számának alakulásában. Amíg a konvencionális ablációk számában minimális emelkedés volt észlelhető, a komplex beavatkozások és ezen belül a pulmonalis véna izolációk számának exponenciális emelkedését látjuk. Jelen közleményben közöljük a fenti években közzétett ablációs számokat és összehasonlítjuk a közép-kelet-európai adatokat valamint az egyes magyarországi centrumok teljesítményét.

Kulcsszavak: elektrofiziológia, katéterabláció, pitvarfibrilláció, ritmuszavar

\section{Numbers of cardiac electrophysiology studies and catheter ablations in Hungary between 2014-2016}

The trend continued from 2014 to 2016 concerning the number of catheter ablations in Hungary. While the number of conventional ablations increased slightly, there was an exponential increase in the number of complex interventions and in the number of pulmonary vein isolations. In this paper, we present the number of ablations performed in the years mentioned above and we compare the Central and Eastern European data, and the performance of each Hungarian centers.

Keywords: electrophysiology, catheter ablation, atrial fibrillation, arrhytmia

\section{Bevezetés}

A szív-elektrofiziológiai vizsgálatok (EP) és katéterablációk száma világszerte, így Magyarországon is ugrásszerüen emelkedik. Ennek több oka is van. A ritmuszavarok alaposabb megismerése, a katéterablációs technikák fejlődése és az utóbbi években kialakult elektrofiziológusi tréningrendszerek a katéterablációs beavatkozások szélesebb körű elterjedését és gyakoribb alkalmazását hozták magukkal. Az ESC- és AHA-ajánlásokban a legtöbb ritmuszavar esetében a katéterabláció elsőként válaszható és választandó beavatkozás lett $(1,2)$. Ha a magyarországi helyzetet szeretnénk megvizsgálni, ezt legkönnyebben a Magyaror- szághoz hasonló adottságú és népességű országokkal történő összehasonlítással tehetjük meg.

\section{Magyarország a közép-kelet-európai régióban}

A korábban publikált adatokkal és a környező országok adataival hasonlítottuk össze a 2014-2016-os eredményeket. A környező országokban az elmúlt 3 évben ez a változás többnyire hasonló volt. Az eddig is fejlett EP-hálózattal rendelkező államok (Ausztria, Csehország) Magyarországhoz hasonló fokú növekedést mutattak, míg a fejlődő régiók (Horvátország, 


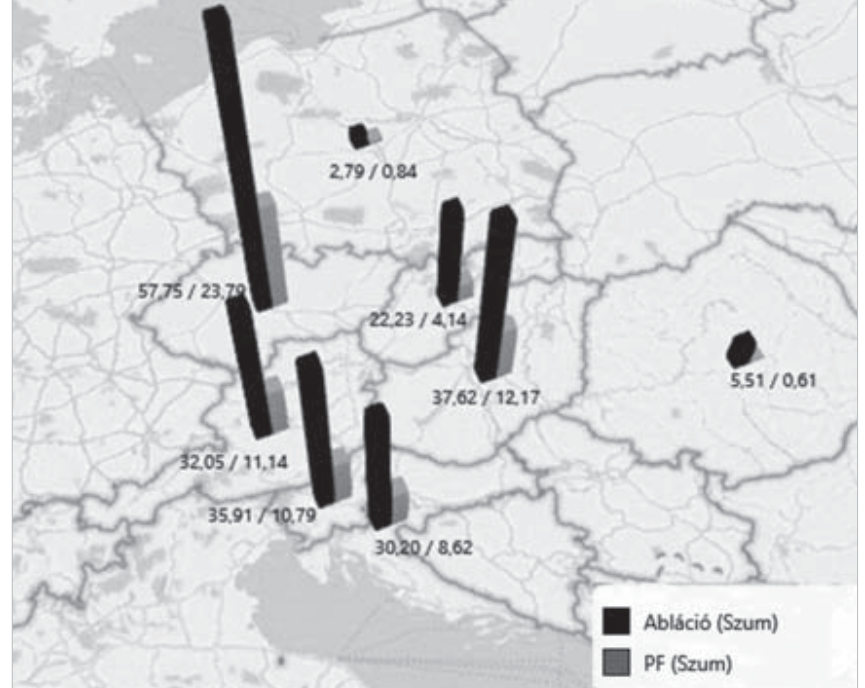

1. ÁBRA. A 100 ezer lakosra vetített összablációk és PF-ablációk száma 2015-ben a kelet-közép-európai régió egyes országaiban

Románia) ennél jóval nagyobb mértékben. Az 1. ábrán jelöltük az egyes országok eredményeit összes ablációszám és komplex abláció (PV-izoláció) tekintetében 100 ezer lakosra vetítve. Az összablációs számokon belül önkényesen kiragadott PV-izoláció használatát azzal magyarázzuk, hogy egy komplex, mégis rutinbeavatkozás révén, jól mutatja egy ország, illetve egy centrum fejlettségét.

\section{A katéterablációk belföldi megoszlása}

Magyarországon belül az elmúlt 3 évben folyamatos emelkedés volt észlelhető a katéterabláció beavatkozások számának tekintetében (2. és 3. ábra). Az 1. táblázatban és a 4. ábrán jól látható, hogy a katéterablációk legnagyobb számban a közép-magyarországi régióban, ezen belül Budapesten történnek. A korábbi évekhez hasonlóan itt is folyamatos a nö-

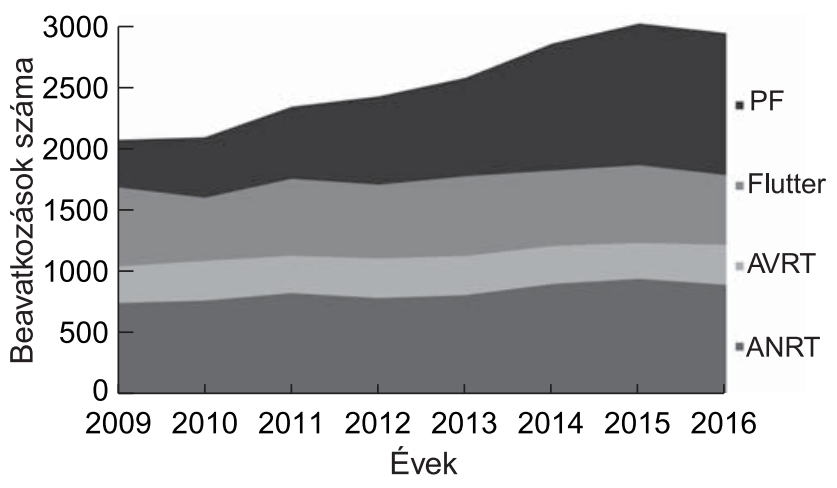

2. ÁBRA. A pitvarfibrilláció, CTI dependens pitvari flutter, AVRT ás AVNRT ablációs beavatkozások számainak alakulása 2009 és 2016 között
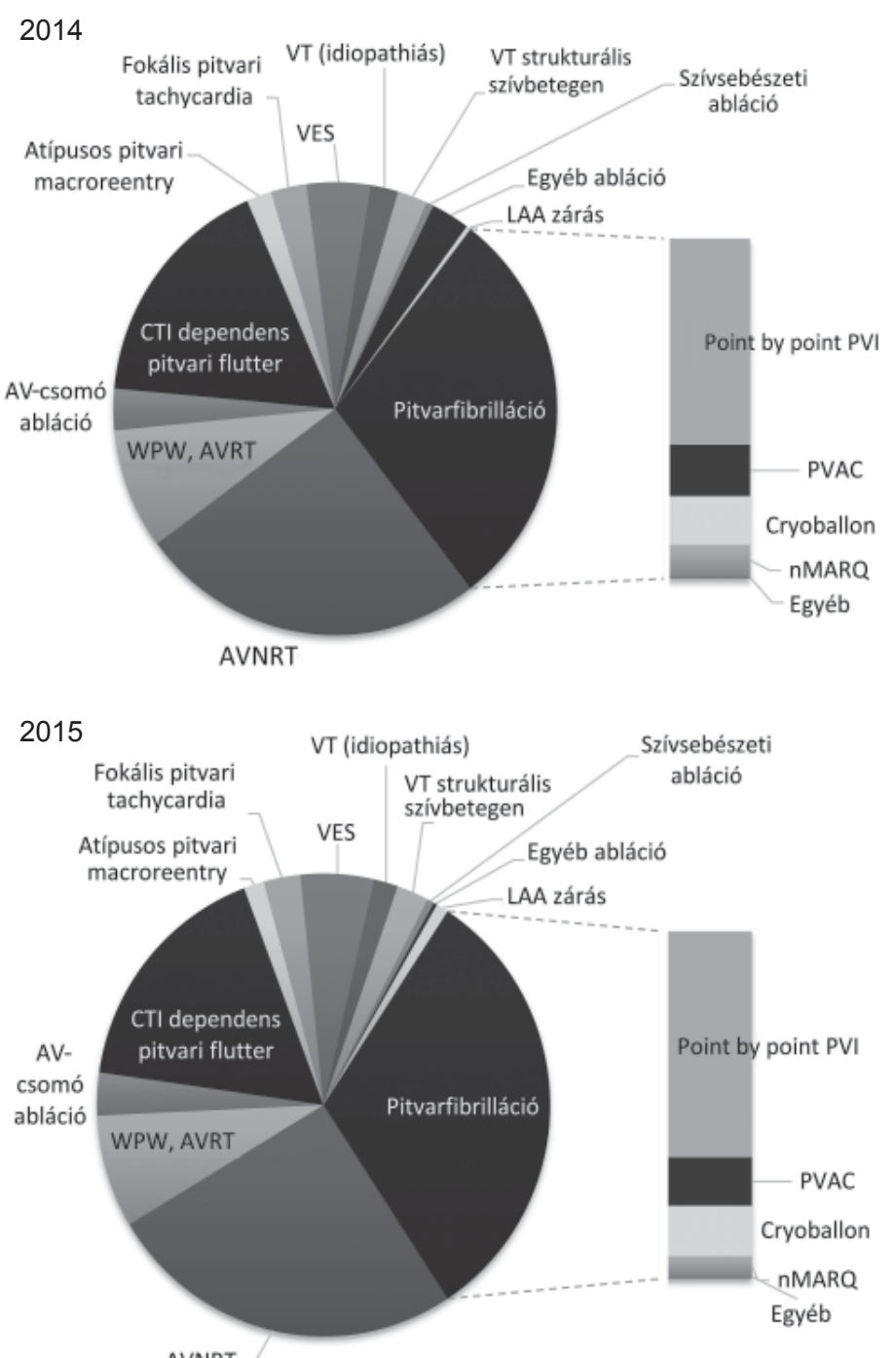

AVNRT

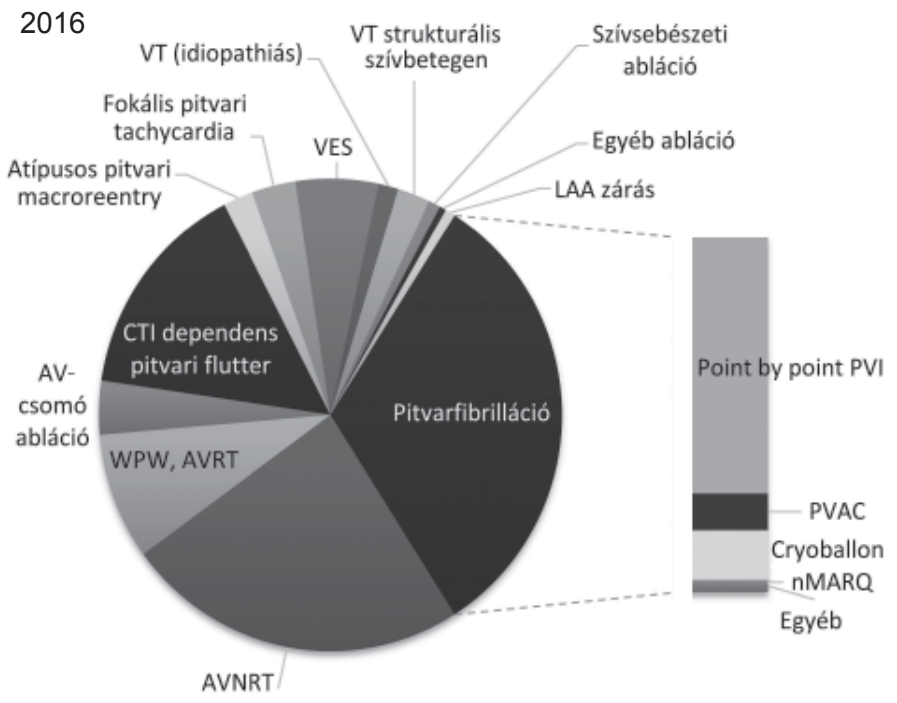

3. ÁBRA. A 2014-2016-os ablációs számadatok megoszlása, kifejtve a pitvarfibrilláció. Rövidítések: CTI: cavo-tricuspid isthmus, PVAC: circular multipolar pulmonary vein ablation catheter, nMARQ: circular multielectrode irigated catheter, LAA: bal pitvari fülcse 


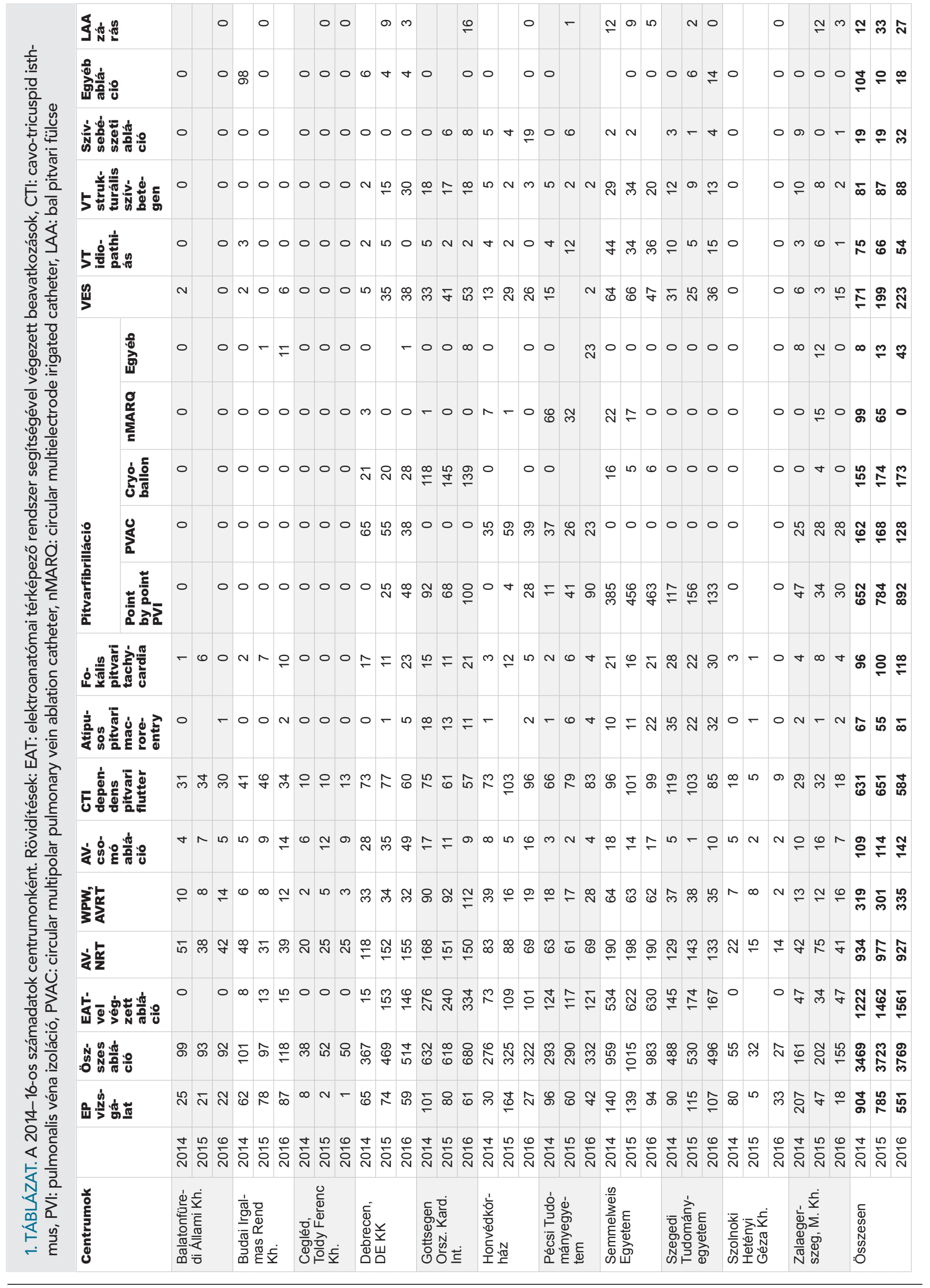




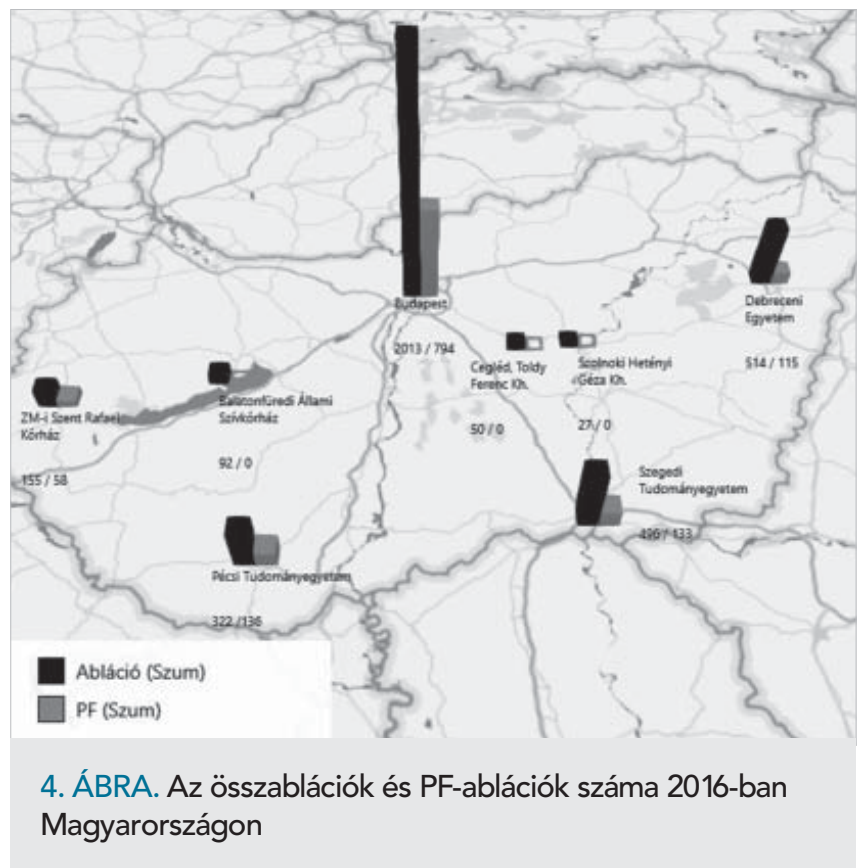

vekedés, azonban egyes centrumokban az emelkedés mértéke eltérő $(3,4)$. Ennek részben finanszírozásbeli, részben személyi okai vannak. Nagy értékü beavatkozások a nagyobb pénzügyi kerettel rendelkező intézményekben, egyetemi és közvetlen állami fenntartású centrumokban könnyebben megvalósíthatók. A vizsgált időszak alatt az ablációk számának emelkedése figyelhető meg, ami részben az egyedi finanszírozású eszközök használatára biztosított keretösszeg emelésével, részint az OEP által a várólista-csökkentésre biztosított külön keret felhasználásával magyarázható. Az 1. táblázat a 2014-2016-os számadatokat foglalja össze centrumonként.

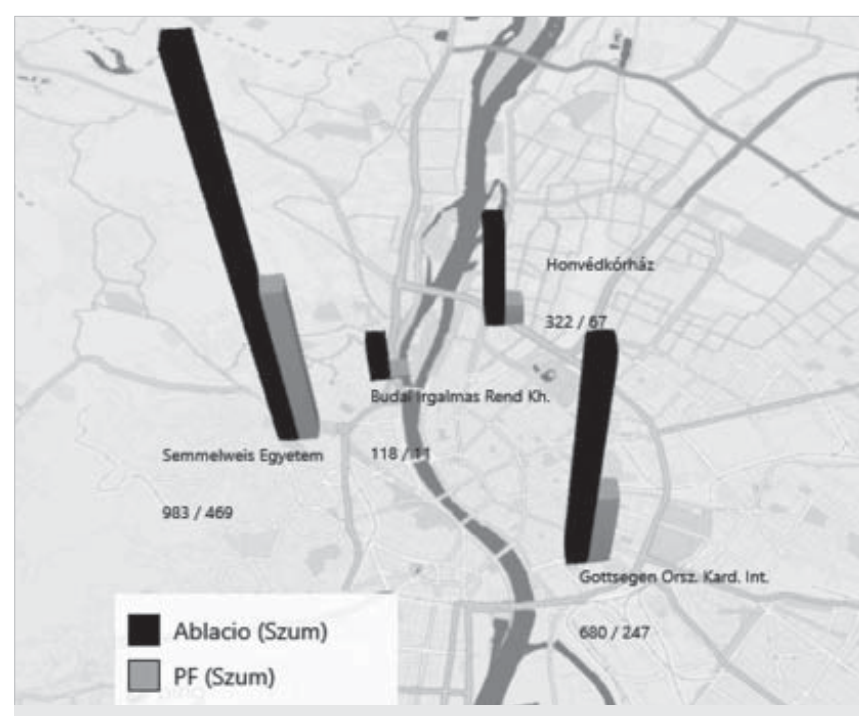

5. ÁBRA. Az összablációk és PF-ablációk száma 2016-ban budapesti centrumokban

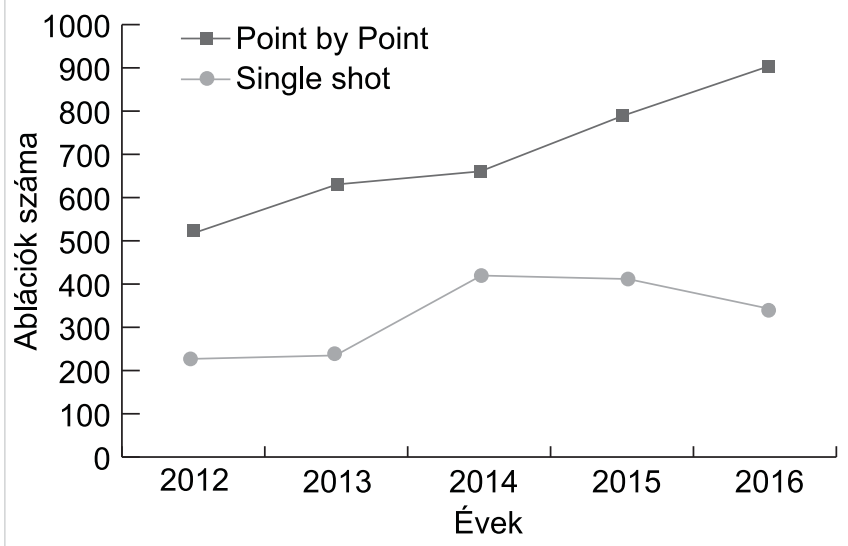

6. ÁBRA. Összehasonlító ábra a „point by point” és „single shot" technikával végzett pitvarfibrilláció abláció számainak alakulásáról 2012 és 2016 között

\section{A PF-abláció szerepe és az ablációs technikák megoszlása}

A pitvarfibrilláció ablációja, a pulmonalis vénák izolációja napjainkban egy nagy számban végzett, de nagy szakértelmet és tárgyi hátteret igénylő beavatkozás. Az 5. ábrán mutatjuk a 2012 és 2016 között végzett PV-izolációkat Magyarországon, külön jelölve a különböző technikákat. Jó látható, hogy a single-shot technikák használata a kezdeti meredeken emelkedő trend után 2014-töl csökkenni látszik. Ennek több magyarázata is lehetséges, a legvalószínübb az, hogy a single-shot RF-módszerekkel (nMarq, PVAC) kapcsolatban leírt súlyos szövődmények visszavetették az ezen módszerek használatával kapcsolatos lelkesedést (5-7).

Az utóbbi pár évben számos olyan tanulmány is napvilágot látott, amelyek leírták a katéterablációs technikák szuperioritását a gyógyszeres antiaritmiás kezeléssel szemben (8). Ezen kívül, új irányt jelent a ballonos krioablációs módszer, amely effektivitása és biztonságossága bizonyítottan noninferior rádiofrekvenciás ablációval szemben (9).

A 6. ábra összehasonlítja a „point by point” és „single shot" techinkával végzett pitvarfibrilláció abláció számainak alakulását 2012 és 2016 között.

\section{Fülcsezárás}

A katéteres fülcsezárás ugyan nem vehető szó szerinti katéterablációs beavatkozásnak, azonban tekintettel arra, hogy a legtöbb EP-centrumban végzik, ide sorolható. A mütét olyan esetekben javallt, amikor magas tromboembóliás rizikó magas vérzéses rizikóval társul, illetve akkor, amikor terápiás szintű antikoagulálás mellett a betegnél stroke alakult ki $(10,11)$. Az elvégzett beavatkozások száma csekély mértékben ugyan, de nőtt 
az évek során, ami azért is kiemelendő, mivel a beavatkozás OEP által történő finanszírozása nem megoldott.

\section{Következtetések}

A 2014 és 2016 közötti vizsgált időszakban a katéterablációk és ezen belül a komplex beavatkozások száma is emelkedést mutatott. Ez részben a beavatkozás szélesebb körű elfogadottságának, részben pedig a bővülő lehetőségeknek köszönhető. Mind közép-kelet-európai összehasonlításban, mind pedig az országon belül öszszevethetőek az adatok. Az elkövetkezendő években remélhetőleg a fentieknek megfelelő folyamat várható.

\section{Irodalom}

1. Kirchhof $P$, Benussi S, Kotecha D, Ahlsson A, Atar D, Casadei B, et al. 2016 ESC Guidelines for the management of atrial fibrillation developed in collaboration with EACTS. Eur J Cardiothorac Surg 2016; 50(5): e1-e88. Epub 2016/09/25. doi: 10.1093/ejcts/ezw313 PubMed PMID: 27663299.

2. Priori SG, Blomstrom-Lundqvist C, Mazzanti A, Blom N, Borggrefe M, Camm J, et al. 2015 ESC Guidelines for the management of patients with ventricular arrhythmias and the prevention of sudden cardiac death: The Task Force for the Management of Patients with Ventricular Arrhythmias and the Prevention of Sudden Cardiac Death of the European Society of Cardiology (ESC). Endorsed by: Association for European Paediatric and Congenital Cardiology (AEPC). Eur Heart J. 2015;36(41):2793-867. Epub 2015/09/01. doi: 10.1093/eurheartj/ehv316. PubMed PMID: 26320108

3. Clemens Marcell GL, Csanádi Z, Zima E. A szív-elektrofiziológiai vizsgálatok és katéterablációk számának alakulása Magyarországon (2009-2010) Cardiologia Hungarica 2011; 315-8.

4. Clemens Marcell SL, Duray G. Pacemaker-implantációk szív-elektrofiziológiai vizsgálatok és katéterablációk számának alakulása hazánkban 2011-2013-ban. Cardiologia Hungarica 2014; 149-54.
5. Burri H, Park Cl, Poku N, Giraudet P, Stettler C, Zimmermann M. Pulmonary Vein Isolation for Paroxysmal Atrial Fibrillation Using a Circular Multipolar Ablation Catheter: Safety and Efficacy Using Low-Power Settings. J Cardiovasc Electrophysiol 2016; 27(2): 170-4. Epub 2015/10/13. doi: 10.1111/jce.12853. PubMed PMID: 26456225.

6. Mahida S, Hooks DA, Nentwich K, Ng GA, Grimaldi M, Shin DI, et al. nMARQ Ablation for Atrial Fibrillation: Results from a Multicenter Study. J Cardiovasc Electrophysiol 2015; 26(7): 724-9. Epub 2015/04/29. doi: 10.1111/jce.12698. PubMed PMID: 25916682

7. Herrera Siklody C, Deneke T, Hocini M, Lehrmann H, Shin DI, Miyazaki S, et al. Incidence of asymptomatic intracranial embolic events after pulmonary vein isolation: comparison of different atrial fibrillation ablation technologies in a multicenter study. J Am Coll Cardiol 2011; 58(7): 681-8. Epub 2011/06/15. doi: 10.1016/j acc.2011.04.010. PubMed PMID: 21664090.

8. Morillo CA, Verma A, Connolly SJ, Kuck KH, Nair GM, Champagne $\mathrm{J}$, et al. Radiofrequency ablation vs antiarrhythmic drugs as first-line treatment of paroxysmal atrial fibrillation (RAAFT-2): a randomized trial. Jama 2014; 311(7): 692-700. Epub 2014/02/20. doi: 10.1001/jama.2014.467 PubMed PMID: 24549549

9. Furnkranz A, Brugada J, Albenque JP, Tondo C, Bestehorn K, Wegscheider K, et al. Rationale and Design of FIRE AND ICE: A multicenter randomized trial comparing efficacy and safety of pulmonary vein isolation using a cryoballoon versus radiofrequency ablation with 3D-reconstruction. J Cardiovasc Electrophysiol. 2014 25(12): 1314-20. Epub 2014/08/26. doi: 10.1111/jce.12529. PubMed PMID: 25146732

10. Holmes DR, Jr., Kar S, Price MJ, Whisenant B, Sievert H, Dosh SK, et al. Prospective randomized evaluation of the Watchman Left Atrial Appendage Closure device in patients with atrial fibrillation versus long-term warfarin therapy: the PREVAIL trial. J Am Coll Cardio 2014; 64(1): 1-12. Epub 2014/07/07. doi:10.1016/j.jacc.2014.04.029 PubMed PMID: 24998121

11. Fountain RB, Holmes DR, Chandrasekaran K, Packer D, Asirvatham S, Van Tassel R, et al. The PROTECT AF (WATCHMAN Left Atrial Appendage System for Embolic PROTECTion in Patients with Atrial Fibrillation) trial. Am Heart J 2006; 151(5): 956-61. Epub 2006/04/29. doi: 10.1016/j.ahj.2006.02.005. PubMed PMID: 16644311.

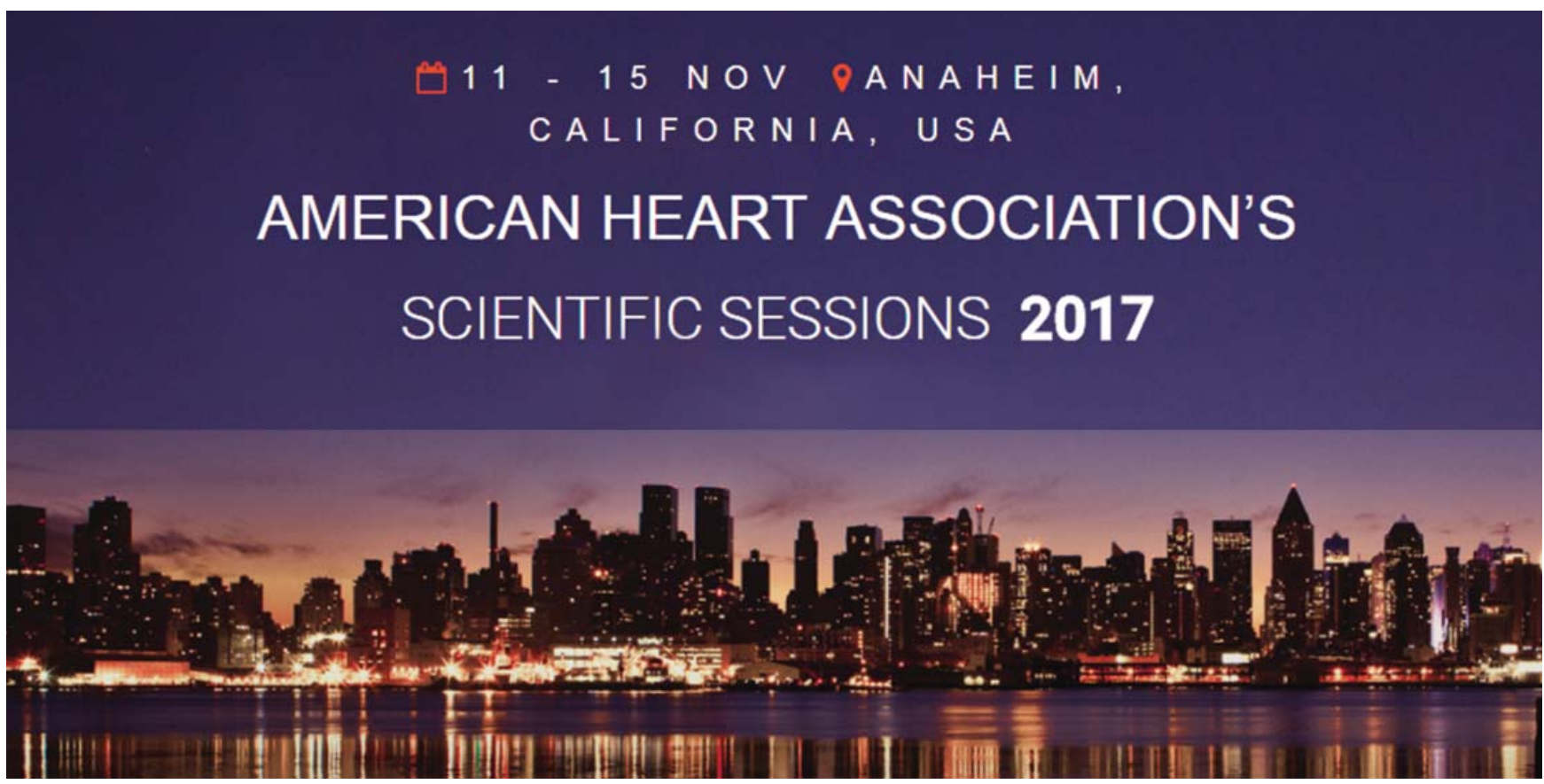

